\title{
Selection of potential iron oxide nanoparticles for breast cancer treatment based on in vitro cytotoxicity and cellular uptake
}

This article was published in the following Dove Press journal:

International Journal of Nanomedicine

19 April 2017

Number of times this article has been viewed

\author{
Johanna M Poller ${ }^{1,2}$ \\ Jan Zaloga' \\ Eveline Schreiber' \\ Harald Unterweger ${ }^{\prime}$ \\ Christina Janko' \\ Patricia Radon ${ }^{3}$ \\ Dietmar Eberbeck ${ }^{3}$ \\ Lutz Trahms ${ }^{3}$ \\ Christoph Alexiou' \\ Ralf P Friedrich' \\ 'Department of Otorhinolaryngology, \\ Head and Neck Surgery, Section \\ for Experimental Oncology \& \\ Nanomedicine (SEON), Else Kröner- \\ Fresenius-Stiftung Professorship, \\ Universitätsklinikum Erlangen, \\ Erlangen, ${ }^{2}$ Friedrich-Alexander- \\ Universität Erlangen-Nürnberg \\ (FAU), ${ }^{3}$ Physikalisch-Technische \\ Bundesanstalt Braunschweig und \\ Berlin, Berlin, Germany
}

\begin{abstract}
Superparamagnetic iron oxide nanoparticles (SPIONs) are promising tools for the treatment of different diseases. Their magnetic properties enable therapies involving magnetic drug targeting (MDT), hyperthermia or imaging. Depending on the intended treatment, specific characteristics of SPIONs are required. While particles used for imaging should circulate for extended periods of time in the vascular system, SPIONs intended for MDT or hyperthermia should be accumulated in the target area to come into close proximity of, or to be incorporated into, specific tumor cells. In this study, we determined the impact of several accurately characterized SPION types varying in size, zeta potential and surface coating on various human breast cancer cell lines and endothelial cells to identify the most suitable particle for future breast cancer therapy. We analyzed cellular SPION uptake, magnetic properties, cell proliferation and toxicity using atomic emission spectroscopy, magnetic susceptometry, flow cytometry and microscopy. The results demonstrated that treatment with dextran-coated SPIONs (SPION ${ }^{\text {Dex }}$ ) and lauric acid-coated SPIONs (SPION ${ }^{\mathrm{LA}}$ ) with an additional protein corona formed by human serum albumin (SPION ${ }^{\mathrm{LA}-\mathrm{HSA}}$ ) resulted in very moderate particle uptake and low cytotoxicity, whereas SPION ${ }^{\mathrm{LA}}$ had in part much stronger effects on cellular uptake and cellular toxicity. In summary, our data show significant dose-dependent and particle type-related response differences between various breast cancer and endothelial cells, indicating the utility of these particle types for distinct medical applications.
\end{abstract}

Keywords: breast cancer, superparamagnetic iron oxide nanoparticles, cellular SPION uptake, toxicity, flow cytometry

\section{Introduction}

Among non-communicable diseases, cancer is the second leading cause of death worldwide after cardiovascular diseases. ${ }^{1}$ Breast cancer is the most common malignancy in women, with a total amount of 1.4 million new cases and 459,000 deaths reported worldwide in 2008. ${ }^{2}$ Apart from local surgery and radiation therapy, there are currently several systemic treatment recommendations. ${ }^{3}$ Although the survival rates for breast cancer showed a steady improvement over the past few decades, systemic chemotherapy results in numerous side effects, including nausea, vomiting, fatigue, weight loss and ovarian failure. ${ }^{4,5}$

In order to improve the efficiency of breast cancer therapy and to minimize its harmful impact on healthy organs and tissues, new treatment regimens are urgently needed. Nanoparticles have gained an increasing importance as promising new tools for drug targeting, hyperthermia and imaging. ${ }^{6-11}$ Especially, biocompatible superparamagnetic iron oxide nanoparticles (SPIONs), which have been in clinical
Correspondence: Christoph Alexiou Department of Otorhinolaryngology, Head and Neck Surgery, Section for Experimental Oncology \& Nanomedicine (SEON), Else Kröner-Fresenius-StiftungProfessorship, Universitätsklinikum Erlangen, Glückstrasse 10a, 91054

Erlangen, Germany

Tel +4991318533142

Fax +49 9|3। 8534828

Email christoph.alexiou@uk-erlangen.de hereby accept the Terms. Non-commercial uses of the work are permitted without any furcther permission from Dove Medical Press Limited, provided the work is properly attributed. For permission for commercial use of this work, please see paragraphs 4.2 and 5 of our Terms (https://www.dovepress.com/terms.php). 
use as contrast agents for magnetic resonance imaging (MRI) to visualize tumors and cardiovascular abnormalities, are exceptionally suitable for cancer therapies. Using SPIONs, hyperthermia of tumor-accumulated particles in the presence of an external alternating magnetic field or magnetic drug targeting (MDT) after SPION conjugation with chemotherapeutic drugs has been reported..$^{8,12-17}$ Additionally, by combining imaging and therapy, SPIONs have the potential to serve as theranostics. ${ }^{18}$

Despite numerous published research papers describing promising nanoparticles for medical applications, only very few nanoparticle types have been translated into the clinics to date. ${ }^{19}$ Usually, the systemic administration of untargeted nanoparticles is followed by adverse side effects and thus prohibits their use for the intended application. In order to reduce systemic side effects, nanoparticles must be as nontoxic and biocompatible as possible and directed to the target region or tissue.

In this investigation, we studied the influence of physicochemical properties of various SPIONs on particle uptake, cell proliferation and viability, in order to select the most suitable candidates for future preclinical applications in vivo. To address the heterogeneity of nanoparticles and cells, we synthesized 3 different, precisely characterized SPIONs (lauric acid-coated SPIONs [SPION ${ }^{\mathrm{LA}}$ ], lauric acidand human serum albumin-coated SPIONs [SPION $\left.{ }^{\mathrm{LA}-\mathrm{HSA}}\right]$ and dextran-coated SPIONs [SPION $\left.{ }^{\text {Dex }}\right]$ ). These particles were chosen because SPION ${ }^{\mathrm{LA}}$ is the direct precursor of SPION $^{\mathrm{LA}-H S A}$, and SPION ${ }^{\mathrm{LA}-H S A}$ and SPION ${ }^{\text {Dex }}$ have previously shown excellent biocompatibility and thus represent highly promising candidates for clinical applications. ${ }^{20,21} \mathrm{We}$ investigated their effects on 4 breast cancer cell lines (T-47D, BT-474, MCF7 and MDA-MB-231) belonging to different subtypes, as defined by receptor expression and proliferation rates. ${ }^{22,23}$ As a tumor-unrelated control, human umbilical vein endothelial cells (HUVECs) were used, which represent a model system for the study of endothelial cells, one of the first cell types that come in contact with nanoparticles after intravascular application.

\section{Materials and methods Materials}

Iron(II) chloride tetrahydrate $\left(\mathrm{FeCl}_{2} \cdot 4 \mathrm{H}_{2} \mathrm{O}\right)$, hydroxylammonium chloride and Eppendorf ultrafiltration tubes with a molecular weight cutoff (MWCO) of $3 \mathrm{kDa}$ were purchased from Merck (Darmstadt, Germany). Iron reference standards $1 \mathrm{~g} / \mathrm{L}$ were bought from Bernd Kraft $\mathrm{GmbH}$ (Duisburg, Germany). Recombinant human serum albumin without octanoate stabilization $\left(\mathrm{AllbIX}^{\circledR}\right)$ was purchased from Albumedix (Nottingham, England). Iron(III) chloride hexahydrate $\left(\mathrm{FeCl}_{3} \cdot 6 \mathrm{H}_{2} \mathrm{O}\right)$, dextran from leuconostoc spp. (molecular weight $40 \mathrm{kDa}$ ), dialysis tubes (Spectra/Por ${ }^{\circledR} 6$, MWCO $8 \mathrm{kDa}$ ), sterile Rotilabo ${ }^{\circledR}$ syringe filters with cellulose mixed ester membranes were supplied by Roth (Karlsruhe, Germany). Spectra/Por 6 dialysis tubing with an MWCO of $10 \mathrm{kDa}$ and a diameter of $29 \mathrm{~mm}$ was purchased from Serva Electrophoresis (Heidelberg, Germany). Propidium iodide (PI), sodium citrate, Triton X-100, ninhydrin, epichlorohydrin, and MEM nonessential amino acid solution $(100 \times)$ were purchased from Sigma-Aldrich (St Louis, MO, USA). DMEM was purchased from Biochrom (Berlin, Germany), Panexin NTA was ordered from PAN-Biotech (Aidenbach, Germany), Insuman Rapid from Sanofi-Aventis (Frankfurt, Germany), L-glutamine from PAA Laboratories (Pasching, Austria) and Ringer's solution was bought from Baxter Healthcare (Zürich, Switzerland). RPMI 1640 and FBS superior were purchased from Thermo Fisher Scientific (Waltham, MA, USA) and endothelial cell growth medium (ECGM) with supplements (C-22010, C-39215) from PromoCell (Heidelberg, Germany). Water used in all experiments was of double-distilled quality.

\section{Synthesis of nanoparticles}

Synthesis of lauric acid-coated iron oxide nanoparticles (SPION ${ }^{\mathrm{LA}}$ )

Iron oxide nanoparticles were synthesized and coated in situ with lauric acid, according to the previously reported method. ${ }^{20}$ Iron(II) and iron(III) salts were dissolved in ultrapure water. Under constant stirring and argon flow, $\mathrm{NH}_{3}$ solution $25 \%$ was added at $90^{\circ} \mathrm{C}$ to precipitate the iron oxides. Then $1.25 \mathrm{~g}$ of lauric acid dissolved in acetone was added. The suspension quickly formed a brownish colloid, which was allowed to cool down and purified by dialysis. The total iron content was determined using microwave plasma atomic emission spectroscopy (MP-AES).

Synthesis of lauric acid- and human serum albumincoated iron oxide nanoparticles (SPION ${ }^{\text {LA-HSA }}$ )

The SPION ${ }^{\text {LA-HSA }}$ particles were synthesized according to a previously published protocol. ${ }^{20}$ AlbIX solution $10 \%(\mathrm{w} / \mathrm{V})$ was placed in dialysis bags (MWCO $8 \mathrm{kDa}$ ) through a $0.22 \mu \mathrm{m}$ sterile filter and dialyzed against $4.5 \mathrm{~L}$ of ultrapure water (4 water changes, $5 \mathrm{~h}$ ). The solution was then concentrated to $20 \mathrm{~mL}$ using tangential ultrafiltration with an MWCO of $30 \mathrm{kDa}$. Then $10 \mathrm{~mL}$ of the respective albumin solution were stirred at $200 \mathrm{rpm}$ at room temperature. SPION ${ }^{\mathrm{LA}}$ was added dropwise to the solution through a $0.8 \mu \mathrm{m}$ syringe filter (final total iron concentration: $2.5 \mathrm{mg} / \mathrm{mL}$ ). It was left 
to homogenate for $10 \mathrm{~min}$ under constant stirring. Excess albumin was then removed from solution using a previously reported tangential ultrafiltration method. ${ }^{24}$ All suspensions were sterilized using a $0.22 \mu \mathrm{m}$ syringe filter. The total iron content was determined using MP-AES.

\section{Synthesis of SPIONDex}

SPION ${ }^{\text {Dex }}$ were synthesized according to a modified procedure by Unterweger et al. ${ }^{25}$ In brief, $\mathrm{FeCl}_{3}$ and $\mathrm{FeCl}_{2}$ in a molar ratio of $\mathrm{Fe}^{3+} / \mathrm{Fe}^{2+}=2$ were added to an aqueous solution containing $8.8 \%(\mathrm{w} / \mathrm{w})$ dextran. Particles were precipitated by adding ammonia to the ice-cooled solution. Afterward, the suspension was heated to $75^{\circ} \mathrm{C}$ for $45 \mathrm{~min}$ and then cooled to room temperature again. Purification of the particles was performed with dialysis and ultrafiltration units. In order to increase the stability of the particles, the dextran shell was cross-linked with epichlorohydrin under basic conditions. Subsequently, the particles were purified by dialysis again and concentrated to a final iron concentration of $\sim 5 \mathrm{mg} / \mathrm{mL}$.

\section{Characterization of nanoparticles} Iron quantification

The total iron content was determined using an Agilent 4200 microwave plasma-atomic emission spectrometer (Agilent Technologies, Santa Clara, CA, USA). Three different aliquots $(50 \mu \mathrm{L})$ of the respective ferrofluid were dissolved in $50 \mu \mathrm{L}$ nitric acid $65 \%$, dissolved for $10 \mathrm{~min}$ at $95^{\circ} \mathrm{C}$ and diluted with $450 \mu \mathrm{L} \mathrm{H}_{2} \mathrm{O}$. The iron content was then determined with MP-AES using a commercial iron solution as external standard. The calibration curve was prepared with iron concentrations ranging from 0.05 to $2.5 \mathrm{mg} / \mathrm{L}$. If the coefficient of determination $\left(R^{2}\right)$ in this given range exceeded 0.999 we proceeded with the experiments.

\section{Magnetic characterization $(M(H)$ - measurement)}

The quasistatic response of the sample magnetization to applied magnetic fields, ie, the $\mathrm{M}(\mathrm{H})$ curve, was measured using a commercial susceptometer (MPMS XL5, Quantum Design, Inc., San Diego, CA, USA). The data were corrected with respect to the magnetization of the empty sample holder as well as the dispersion medium. The uncertainty of the magnetization is for the here measured samples of order of $1.5 \%$, mainly due to uncertainties of sample positioning affecting the sensitivity and the correctness of sample holder subtraction. In order to get the specific magnetization $\mathrm{M}$, we divided $\mathrm{M}$ by the volume fraction of magnetite, which is estimated from the iron content of the sample. In order to circumvent uncertainties arising from sample handling, the $\mathrm{M}(\mathrm{H})$-sample was dissolved in $\mathrm{HCl}$ after $\mathrm{M}(\mathrm{H})$ measurement within its sample holder. The dissolved iron was then quantified by the phenanthroline staining method. A commercial iron standard served as reference. The uncertainty of the quantification is $\sim 1.5 \%$.

\section{Dynamic light scattering (DLS) and zeta potential measurements}

The hydrodynamic sizes and zeta potentials in water and cell culture media were determined using a Malvern Zetasizer Nano ZS (Malvern Instruments, Worcestershire, England). The particles were diluted to a total iron concentration of $30 \mu \mathrm{g} / \mathrm{mL}$ with ultrapure water and FCS-free RPMI 1640 cell culture media, respectively, and measured in triplicates at $25^{\circ} \mathrm{C}$.

\section{Sedimentation tendency of nanoparticles}

SPIONs were diluted to $75 \mu_{\mathrm{Fe}} / \mathrm{mL}$ with $\mathrm{H}_{2} \mathrm{O}, \mathrm{DMEM}$, DMEM supplemented with $10 \%$ FCS or ECGM with $2 \%$ FCS. After $45 \mathrm{~min}$, samples and controls without SPIONs were centrifuged at $2,500 \times g$ for $5 \mathrm{~min}$ and $22^{\circ} \mathrm{C}$. Then $50 \mu \mathrm{L}$ aliquots of the supernatants were digested with $100 \mu \mathrm{L}$ nitric acid $65 \%$ for $10 \mathrm{~min}$ at $95^{\circ} \mathrm{C}$ and diluted with $850 \mu \mathrm{L} \mathrm{H} \mathrm{H}_{2} \mathrm{O}$ before iron concentration were determined by MP-AES. Uncentrifuged aliquots served as maximum positive controls and were used to estimate the sedimentation tendency and stability of SPIONs in different fluids. Experiments were done in triplicates.

\section{Blood stability assay}

Blood stability of the particles was investigated using freshly drawn human blood samples. Then $200 \mu \mathrm{L}$ EDTA-stabilized blood was incubated with $100 \mu \mathrm{L}$ ferrofluid $\left(2 \mathrm{mg}_{\mathrm{Fe}} / \mathrm{mL}\right)$ for $60 \min (n=3)$. Then $2 \mu \mathrm{L}$ of the respective sample was streaked on a glass slide and investigated with a Zeiss Axio Observer Z1 microscope (Zeiss, Jena, Germany). $\mathrm{H}_{2} \mathrm{O}$ was used as a control.

\section{Cell culture and sample preparation}

\section{Cells and culture conditions}

Breast cancer cell lines T-47D (ATCC ${ }^{\circledR}$ HTB-133 ${ }^{\mathrm{TM}}$ ), BT-474 (ATCC ${ }^{\circledR} \mathrm{HTB}^{2}-2{ }^{\mathrm{TM}}$ ), MCF7 (ATCC ${ }^{\circledR} \mathrm{HTB}^{2} 22^{\mathrm{TM}}$ ) and MDA-MB-231 (ATCC ${ }^{\circledR}$ HTB-26 ${ }^{\mathrm{TM}}$ ) were purchased from ATCC (Manassas, VA, USA). T-47D was cultivated in RPMI1640 with 0.1 units $/ \mathrm{mL}$ human insulin, $2 \mathrm{mM}$ L-glutamine and 10\% FCS, BT-474 in DMEM (F0445) with $2 \mathrm{mM}$ L-glutamine, $12 \%$ Panexin NTA and $8 \%$ FCS, MCF7 in DMEM (F0475) with $2 \mathrm{mM}$ L-glutamine and 10\% FCS and MDA-MB231 in DMEM (FG0445) with 2 mM L-glutamine, 10\% FCS and $1 \%$ MEM nonessential amino acid solution at $37^{\circ} \mathrm{C}$ 
and $5.0 \% \mathrm{CO}_{2}$. Primary HUVECs were purchased from PromoCell (Heidelberg, Germany). HUVECs were used at passage 3-5 and cultivated in ECGM with supplements at $37^{\circ} \mathrm{C}$ and $5.0 \% \mathrm{CO}_{2}$. For further passaging, trypsinization was performed according to the manufacturer's instructions.

\section{Preparation of cell-based experiments}

Cells were seeded into 6-well and 24-well cell culture plates in a total volume of 2.5 and $0.5 \mathrm{~mL}$, respectively. The amount of seeded cells depended on the growth rate of the individual cell lines and was calculated to achieve a final confluency of $95 \%$ after 72 h. After 24 h, SPIONs (SPION ${ }^{L A}$, SPION ${ }^{\text {LA-HSA }}$ and SPION ${ }^{\text {Dex }}$ ) were added to a final concentration of 0,25 , 50 and $75 \mu \mathrm{g}_{\mathrm{Fe}} / \mathrm{mL}$ cell culture media, which corresponds to $0,7.0,14.0$ and $21.0 \mu \mathrm{g}_{\mathrm{Fe}} / \mathrm{cm}^{2}$ cell culture plate area. Thus, the correlation between SPION concentration in cell culture media and on plate surface area was kept constant for all experiments. The negative control contained $0 \mu \mathrm{g}_{\mathrm{Fe}} / \mathrm{mL}$ cell culture media, and the toxicity control 1.5\% DMSO. Subsequently, cells were incubated for another 24 or $48 \mathrm{~h}$ before analysis. The 6-well samples were harvested, and the cell pellets were resuspended in $0.5 \mathrm{~mL}$ phosphate-buffered saline (PBS). Cell suspensions were used to determine the absolute cell counts with the MUSE $^{\circledR}$ Cell Analyzer (Merck-Millipore, Billerica, MA, USA), as well as for flow cytometry analysis and SPION quantification measurements using MP-AES. The 24-well samples were stained with Prussian blue or Alexa Fluor 488 Phalloidin/Hoechst 33342 for imaging. All cell-based experiments were performed in 4 independent experiments with triplicates.

\section{Cellular toxicity measurements of SPIONs by flow cytometry}

Cell granularity and cell viability were determined by flow cytometry using a Gallios cytofluorometer (Beckman Coulter, Fullerton, CA, USA). ${ }^{26,27}$ For cell death analysis, $50 \mu \mathrm{L}$ aliquots of cell suspension were incubated with $250 \mu \mathrm{L}$ of freshly prepared staining solution for $20 \mathrm{~min}$ at $4^{\circ} \mathrm{C}(1 \mathrm{~mL}$ staining solution contains $1 \mu \mathrm{L}$ annexin $\mathrm{V}(\mathrm{AxV})$-FITC,

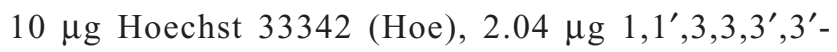
hexamethylindodicarbocyanine iodide (DiIC1(5)) (all from Thermo Fisher Scientific) and 66.6 ng PI (Sigma-Aldrich, Taufkirchen, Germany) in Ringer's solution (Fresenius Kabi AG, Bad Homburg, Germany). The side scatter (SSc) was extracted from the flow cytometric measurements after gating on phenotypically healthy cells, characterized by AxV negative and PI negative staining. Every sample was measured for a fixed time (120 s). For the analysis of cell cycle and DNA degradation, $200 \mu \mathrm{L}$ of the cell suspensions were fixed by adding $3 \mathrm{~mL}$ of $70 \%(\mathrm{v} / \mathrm{v})$ ice-cold ethanol and stored at $-20^{\circ} \mathrm{C}$ for further processing. ${ }^{28}$ The cells were then centrifuged $\left(5 \mathrm{~min}, 450 \times \mathrm{g}, 24^{\circ} \mathrm{C}\right)$, the supernatant was removed, and the cells were washed with PBS once. Then the cells were resuspended in $0.5 \mathrm{~mL}$ PBS and $0.5 \mathrm{~mL}$ DNA extraction buffer (192 mL of $0.2 \mathrm{M} \mathrm{Na}_{2} \mathrm{HPO}_{4}, 8 \mathrm{~mL} 0.1 \%$ Triton X-100 [v/v], pH 7.8) was added and incubated for additional $5 \mathrm{~min}$ at room temperature (RT). Cells were centrifuged ( $5 \mathrm{~min}, 450 \times \mathrm{g}, 24^{\circ} \mathrm{C}$ ), the supernatant was removed and cells were resuspended in $0.4 \mathrm{~mL}$ DNA staining solution $(20 \mu \mathrm{g} / \mathrm{mL}$ PI and $200 \mu \mathrm{g} / \mathrm{mL}$ Ribonuclease A in PBS) and incubated for $30 \mathrm{~min}$ at RT in the dark. Electronic compensation was used to eliminate bleed-through fluorescence. Data analysis was performed with Kaluza software version 1.2 (Beckman Coulter). All flow cytometry experiments were performed with triplets in 4 independent experiments.

\section{Quantification of cellular SPIONs by MP-AES}

The absolute iron content was determined by MP-AES. A total of $200 \mu \mathrm{L}$ cell suspension was centrifuged for $5 \mathrm{~min}$ at $1,000 \times g$. The supernatants were aspirated and the pellets stored at $-20^{\circ} \mathrm{C}$ until measurement. The cell pellets were then dissolved in $50 \mu \mathrm{L}$ nitric acid $65 \%$, incubated at $90^{\circ} \mathrm{C}$ for 10 min with a shaking incubator and diluted to $450 \mu \mathrm{L}$ with ultrapure water. The total iron content of the cells was then determined using the MP-AES method, which was described earlier. The iron content was normalized to the total number of cells in the analyzed cell pellet.

\section{Imaging of SPION-treated cells after Prussian blue and immunofluorescent staining}

Cellular F-actin, SPION aggregates and nuclei of SPIONtreated and untreated cells were visualized after $48 \mathrm{~h}$. After washing the cells twice with PBS, the cells were fixed for 20 min with 4\% PBS-buffered formalin, washed twice, permeabilized for 3 min with Triton X-100 (0.5\% in PBS) and washed again twice with PBS. Cells intended for Prussian blue staining were incubated for 30 min with Prussian blue staining solution ( $2 \%$ potassium hexacyanoferrate(II) in $2 \% \mathrm{HCl}$ ) and washed 3 times with PBS. Cells chosen for fluorescence imaging were incubated for 20 min with Alexa Fluor 488 Phalloidin (1:75) to visualize F-actin and Hoechst 33334 (1:2,500; Molecular Probes, Life Technologies, Carlsbad, CA, USA) to visualize nuclei, followed by washing 3 times with PBS. Finally, the stained cells were imaged with a Zeiss Axio Observer. Z1 fluorescent microscope (Carl Zeiss AG, Oberkochen, Germany). 


\section{Results}

\section{Characterization of SPIONs}

The magnetic properties of 3 synthesized SPION types were investigated. The $\mathrm{M}(\mathrm{H})$ data demonstrated that the saturation was not achieved even at the magnetic field of $5 \mathrm{~T}$, but almost attained the Ms value of magnetite, which is $480 \mathrm{kA} / \mathrm{m}$ (Figure 1A). ${ }^{29}$
The highest degree of saturation was observed for SPION ${ }^{\mathrm{LA}}$. In SPION ${ }^{\mathrm{LA}-\mathrm{HSA}}$ samples, which showed a similar shape of saturation curve, saturation magnetization was by $7 \% \pm 3 \%$ smaller than SPION ${ }^{\mathrm{LA}}$ (Figure 1A). However, a more detailed analysis also revealed differences in the shape of $\mathrm{M}(\mathrm{H})$ of $8 \%$ at low fields (Figure 1B). Thus, the slightly reduced saturation
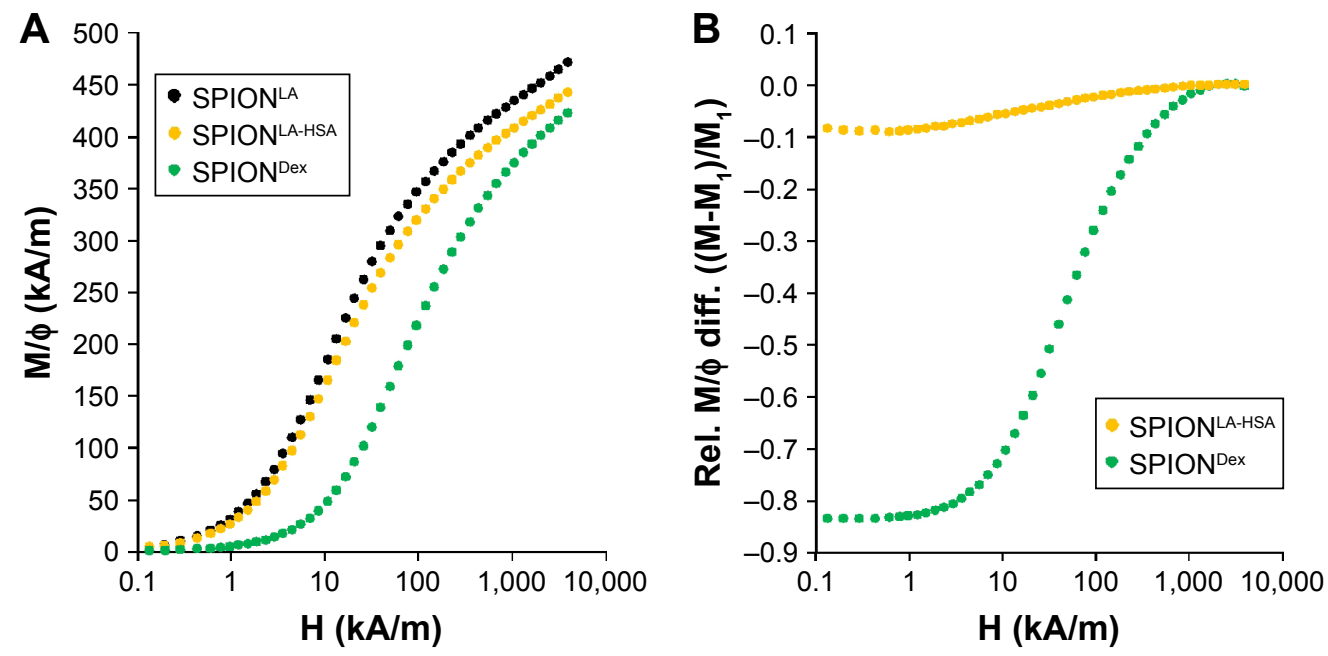

\begin{tabular}{|c|c|c|c|}
\hline & SPIONLA & SPIONLA-HSA & SPIONDex \\
\hline $\mathrm{Z}$ ave. $\varnothing$ in $\mathrm{H}_{2} \mathrm{O}(\mathrm{nm})$ & $44.6 \pm 0.1$ & $57.3 \pm 0.4$ & $78.9 \pm 1.9$ \\
\hline$Z$ ave. $\varnothing$ in media $(0 \%$ FCS) $(\mathrm{nm})$ & n.m..$_{\text {sed. }}$ & $54.2 \pm 1.5$ & $73.5 \pm 2.2$ \\
\hline$Z$ ave. $\varnothing$ in media $(10 \%$ FCS) $(\mathrm{nm})$ & n.m. FCS & n.m..$_{\text {FCS }}$ & n.m..$_{\text {FCS }}$ \\
\hline Zeta potential in $\mathrm{H}_{2} \mathrm{O}(\mathrm{pH} \sim 7)(\mathrm{mV})$ & $-50.6 \pm 0.9$ & $-39.2 \pm 1.0$ & $-9.4 \pm 0.6$ \\
\hline Zeta pot. in media (0\% FCS; pH 7.4) (mV) & n.m. & $-10.0 \pm 0.8$ & $-7.2 \pm 1.5$ \\
\hline Zeta pot. in media (10\% FCS; pH 7.4) (mV) & n.m. $\cdot_{\text {FCS }}$ & n.m..$_{\text {FCS }}$ & n.m..$_{\text {FCS }}$ \\
\hline Sedimentation in $\mathrm{H}_{2} \mathrm{O}(\%)$ & $3.4 \pm 0.9$ & $6.5 \pm 2.9$ & $3.2 \pm 3.0$ \\
\hline Sedimentation in media with 0\% FCS (\%) & $95.6 \pm 4.1$ & $5.7 \pm 1.9$ & $2.2 \pm 0.0$ \\
\hline Sedimentation in media with $2 \%$ FCS (\%) & $34.2 \pm 2.1$ & $6.9 \pm 2.2$ & $1.1 \pm 1.3$ \\
\hline Sedimentation in media with $10 \%$ FCS (\%) & $5.8 \pm 1.7$ & $4.1 \pm 3.2$ & $1.8 \pm 1.6$ \\
\hline
\end{tabular}

D

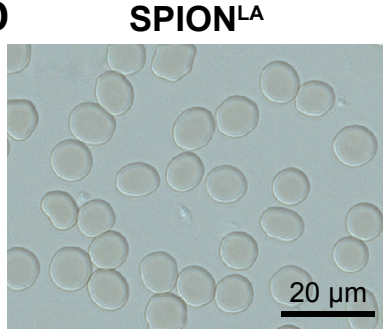

SPION LA-HSA

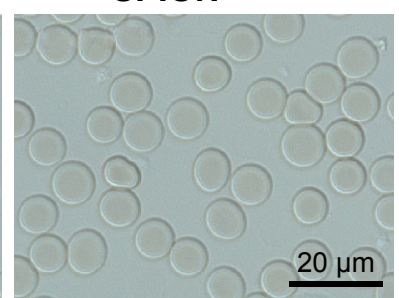

SPIONDex

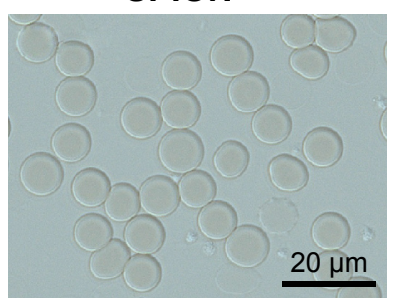

\section{Negative control*}

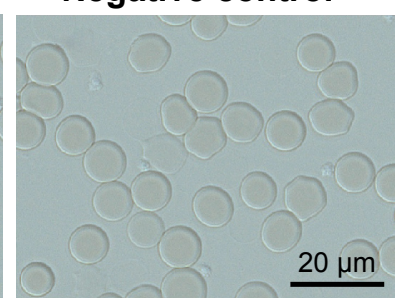

Figure I Biophysical properties of superparamagnetic iron oxide nanoparticles.

Notes: $(\mathbf{A}) \mathrm{M}(\mathrm{H})$ curves of indicated samples normalized with respect to the volume fraction of magnetite. The uncertainty of $M$ at high fields $(>1000 \mathrm{kA} / \mathrm{m})$ amounts to about $2 \%$. (B) Relative differences of the data sets with respect to SPION ${ }^{L A}\left(M_{1}\right)$ after its normalization at high fields. (C) Summary of the biophysical properties of SPION ${ }^{L A}$, SPION ${ }^{L A-H S A}$ and SPIONDex particles measured in water, FCS-free media and media containing FCS, respectively. Sedimentation data refer to the amount of particles sedimented after centrifugation and are considered as an indicator of the particles' sedimentation propensity. (D) Stability of SPIONs in human blood. *Negative control = corresponding amount of $\mathrm{H}_{2} \mathrm{O}$ instead of water-based ferrofluid. Representative images were recorded using optical bright-field microscopy.

Abbreviations: SPION, superparamagnetic iron oxide nanoparticles; SPION ${ }^{L A}$, lauric acid-coated SPIONs; SPION ${ }^{L A-H S A}$, lauric acid- and human serum albumin-coated SPIONs; SPIONDex, dextran-coated SPIONs; pot., potential; rel., relative; diff., difference; $Z$ ave. $\varnothing$, average particle diameter; n.m.sed., not measurable due to sedimentation; n.m.FCS, not measurable due to FCS interference; $M(H)$, magnetization in dependence of applied magnetic field. 
magnetization of SPION ${ }^{\mathrm{LA}-\mathrm{HSA}}$ compared to its precursor SPION $^{\mathrm{LA}}$ seems to be linked to some slight changes in the particle magnetic moments, probably due to their coating with human serum albumin. Hence, the high similarity between SPION ${ }^{\mathrm{LA}-\mathrm{HSA}}$ and SPION ${ }^{\mathrm{LA}}$ reflects the identical origin of these particle systems, as SPION ${ }^{\mathrm{LA}-\mathrm{HSA}}$ is produced from SPION ${ }^{\mathrm{LA}}$. In contrast to the lauric acid-based SPIONs, SPION ${ }^{\text {Dex }}$ showed a much weaker magnetization course, most likely caused by the relatively small particle core size. ${ }^{30}$

To further characterize the nanoparticles, we investigated the surface properties and particle size, as these parameters play a key role in determining the nanoparticle-cell interactions. ${ }^{31}$ The surface properties are usually altered by the presence of proteins in the solvent, which leads to the formation of a complex dynamic corona that can influence nanoparticle stability, uptake and toxicity. ${ }^{32,33} \mathrm{We}$, therefore, performed biophysical SPION characterization not only in water but also in more complex physiological fluids, such as cell culture media with or without FCS (Figure 1C). In distilled water, the measured hydrodynamic diameter of SPION ${ }^{\mathrm{LA}}$ was $44.6 \mathrm{~nm}$, of SPION ${ }^{\text {LA-HSA }}$ was $57.3 \mathrm{~nm}$ and of SPION ${ }^{\text {Dex }}$ was $78.9 \mathrm{~nm}$. Interestingly, when using FCS-free cell culture media the particle size of SPION ${ }^{\mathrm{LA}-\mathrm{HSA}}$ and SPION ${ }^{\mathrm{Dex}}$ did not change significantly, suggesting a very stable particle system. In contrast, the average particle diameter of SPION ${ }^{\mathrm{LA}}$ increased exorbitantly compared with the hydrodynamic diameter measured in distilled water, indicating a strong dependence of the particle stability on the ionic composition of the solvent, which results in a strong particle agglomeration and sedimentation. This result confirmed that 1) the stability of SPIONs that are primarily coated with fatty acids is dependent on low ionic strength, constant excess of the surfactant and alkaline $\mathrm{pH}$ and that 2) the protein corona contributes to an enhanced colloidal stability. ${ }^{34-36}$

We then investigated the surface charge of particles diluted in water and FCS-free cell culture media (Figure 1C). In water, SPION ${ }^{\mathrm{LA}}$ and SPION ${ }^{\mathrm{LA}-\mathrm{HSA}}$ displayed a strong negative zeta potential $(-50.6 \mathrm{mV}$ and $-39.2 \mathrm{mV}$ respectively), whereas SPION ${ }^{\text {Dex }}$, containing an uncharged dextran coating, exhibited a slightly negative zeta potential $(-9.4 \mathrm{mV})$. The presence of FCS-free media changed the surface potential of SPION ${ }^{\mathrm{LA}-\mathrm{HSA}}$ to $-10.0 \mathrm{mV}$, whereas the value for SPION $^{\text {Dex }}$ particles was not significantly influenced. Due to the enhanced instability and sedimentation of SPION ${ }^{\mathrm{LA}}$ particles in the presence of FCS-free media, zeta potential measurements were not possible.

Characteristics of SPIONs were further altered upon suspending the particles into FCS-containing cell culture media.
Since FCS contains a huge amount of proteins and corpuscular compounds, which massively affect the analysis, DLS-related measurements in FCS were not feasible. Centrifugation experiments of SPION suspensions $\left(75 \mu \mathrm{g}_{\mathrm{Fe}} / \mathrm{mL}\right)$ in different fluids revealed a fluid- and particle-dependent sedimentation during centrifugation, indicating a differential sedimentation propensity within cell culture experiments (Figure 1C). SPION $^{\mathrm{LA}}$, which are extremely unstable in media without supplements (95.6\% sedimentation), were highly stabilized in the presence of FCS in a dose-dependent manner (34.2\% sedimentation in 2\% FCS and only $5.8 \%$ sedimentation in $10 \%$ FCS-containing media). This suggested the development of a stabilizing protein corona and, consequently, a decreased aggregation and sedimentation propensity compared to samples diluted in water or FCS-free media. Incubation of SPION $^{\mathrm{LA}-\mathrm{HSA}}$ and SPION ${ }^{\text {Dex }}$ with FCS did not greatly change their sedimentation tendency. Taken together, these data suggest a highly dynamic corona formation in the presence of different fluids, which might equalize the cellular response of basically very different nanoparticles.

The stability of nanoparticles was further investigated in EDTA-anticoagulated human blood at a microscopic level (Figure 1D). Due to the addition of aqueous SPION suspension and control dilutions, erythrocytes display a slight swelling which was identical in all samples. Interestingly, all SPIONs used in this study were stable and did not show any sign of agglomeration in blood. Moreover, the morphology of erythrocytes was indistinguishable in all samples. Similar results were achieved in citrate-stabilized blood and plasma (data not shown). These assays clearly show the good biostability of all 3 particle systems and indicate their possible usage for in vivo experiments.

\section{Cellular SPION uptake}

Besides the therapeutic efficiency of nanoparticles, which is primarily dictated by the functionalization with chemotherapeutics, it is crucial that they are stable in physiological fluids and do not induce adverse effects in their nonfunctionalized precursor form. We, therefore, investigated the biological outcomes in several breast cancer cell lines exposed to different SPION types in order to evaluate their potential for future medicinal applications.

For this purpose, the effects of SPION ${ }^{\mathrm{LA}}$, SPION ${ }^{\mathrm{LA}-\mathrm{HSA}}$ and SPION ${ }^{\text {Dex }}$ on the breast cancer cell lines T47-D, BT-474, MCF7 and MDA-MB-231 and, as a control, on primary endothelial cells (HUVECs) were investigated. HUVECs were included into these analyses, as a model system for the study of endothelial cells, which are the first-contact cells for 
intravenously or intra-arterially administrated nanosystems and are in particular expected to be affected very intensely after MDT. ${ }^{37}$

To investigate a potential concentration-, time-, particleand cell-dependent cellular uptake of SPIONs, we treated T47-D, BT-474, MCF7, MDA-MB-231 and HUVECs with 0-75 $\mu_{\mathrm{Fe}} / \mathrm{mL} \mathrm{SPION}^{\mathrm{LA}}$, SPION ${ }^{\mathrm{LA}-\mathrm{HSA}}$ or SPION ${ }^{\text {Dex }}$ for 24 and $48 \mathrm{~h}$ (Figures 2, 3 and $\underline{\mathrm{S} 1}-\underline{\mathrm{S} 7}$ ). To quantify the cellular SPION content, we used MP-AES, a sensitive and reliable method to determine the amount of elementary iron (Figures 2 and S1). ${ }^{38}$ With a few exceptions, most samples displayed slightly lower iron content values after $48 \mathrm{~h}$ compared to those incubated for $24 \mathrm{~h}$, most likely as a result of cell proliferation and division of the SPION content to the daughter cells. Depending on the SPION type, we found substantial differences in the iron amount within the investigated cells. SPION ${ }^{\mathrm{LA}}$ uptake was
A

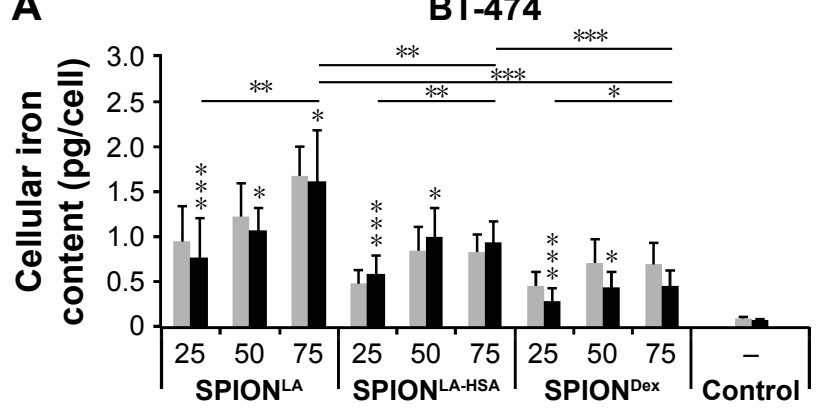

SPION concentration ( $\mu \mathrm{g} / \mathrm{mL}$ cell medium)

C

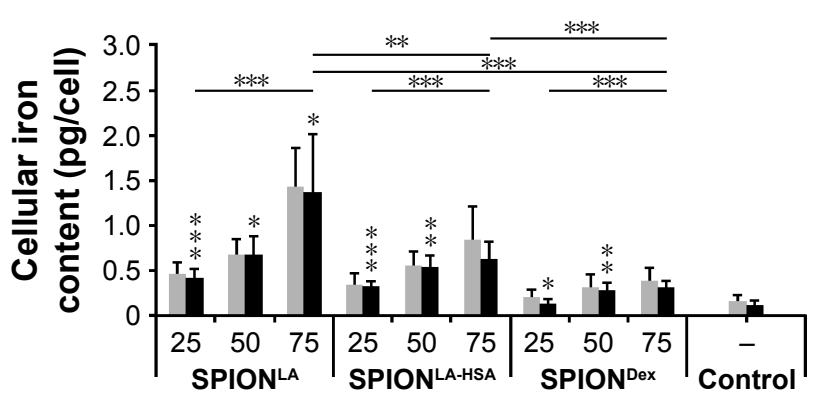

SPION concentration $(\mu \mathrm{g} / \mathrm{mL}$ cell medium)
B

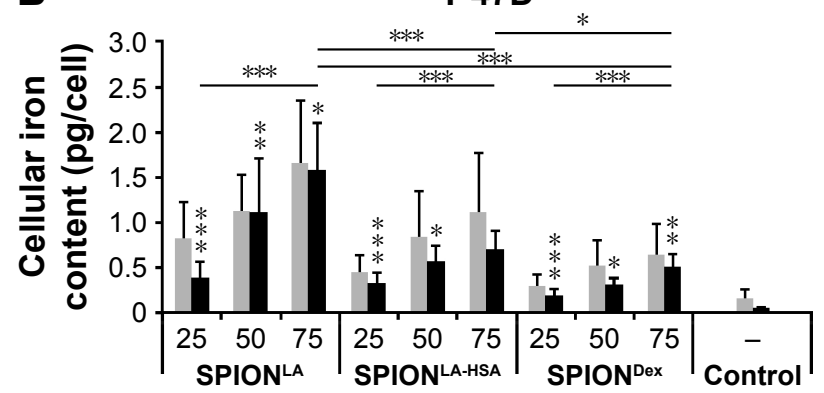

SPION concentration $(\mu \mathrm{g} / \mathrm{mL}$ cell medium)

D MDA-MB-231

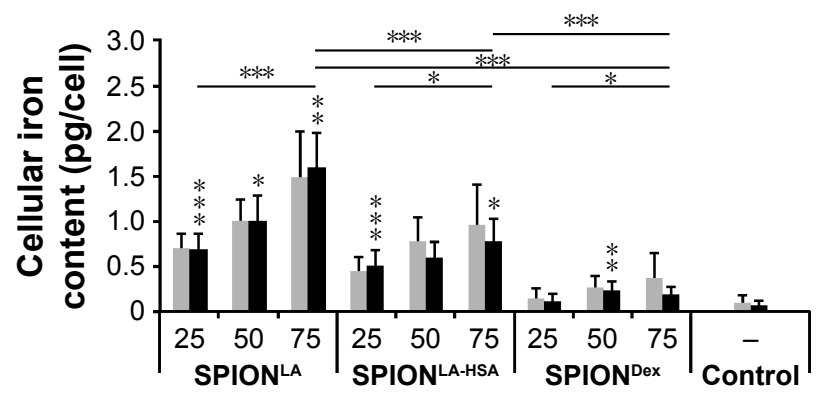

SPION concentration $(\mu \mathrm{g} / \mathrm{mL}$ cell medium)

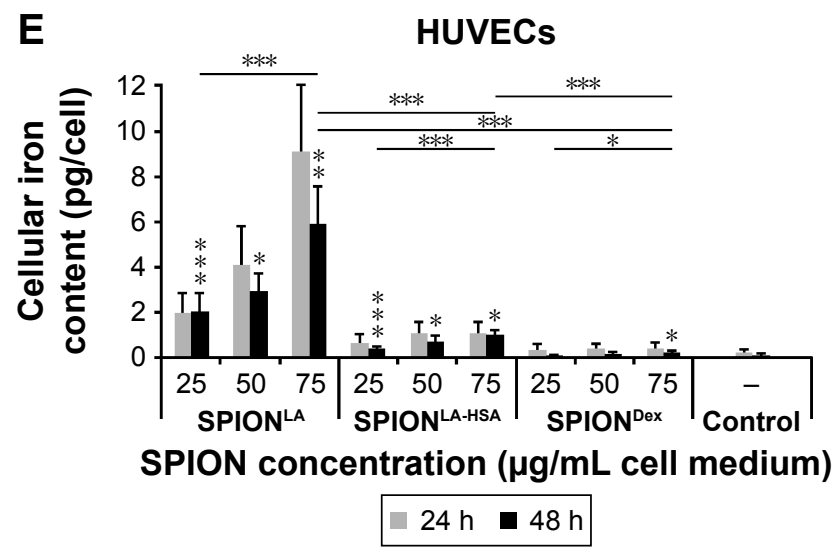

Figure 2 Quantification of the cellular nanoparticle load via MP-AES.

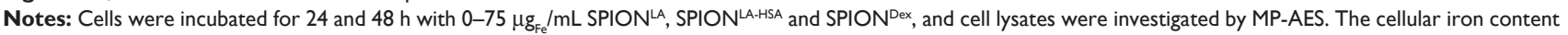
(pg/cell) is shown for (A) BT-474, (B) T-47D, (C) MCF7, (D) MDA-MB-23I and (E) HUVECs. Negative controls are samples with corresponding amount of $\mathrm{H}_{2} \mathrm{O}$ instead of water-based ferrofluid. The data are expressed as the mean \pm standard deviation ( $\mathrm{n}=4$ with technical triplicates). Statistical significance of $48 \mathrm{~h}$ data sets are indicated with $* P<0.05, * * P<0.001$ and $* * * P<0.0001$ and were calculated via Student's $t$-test analysis. Asterisks shown directly on bars indicate dose-dependent significance to the next lower SPION concentration. Asterisks over the lines indicate dose-dependent significance between lowest and highest SPION concentrations and between the highest SPION concentrations of different SPIONs.

Abbreviations: MP-AES, microwave plasma-atomic emission spectroscopy; SPION, superparamagnetic iron oxide nanoparticles; SPION ${ }^{L A}$, lauric acid-coated SPIONs; SPION ${ }^{\text {LA-HSA }}$, lauric acid- and human serum albumin-coated SPIONs; SPION ${ }^{\text {Dex }}$, dextran-coated SPIONs; HUVECs, human umbilical vein endothelial cells. 


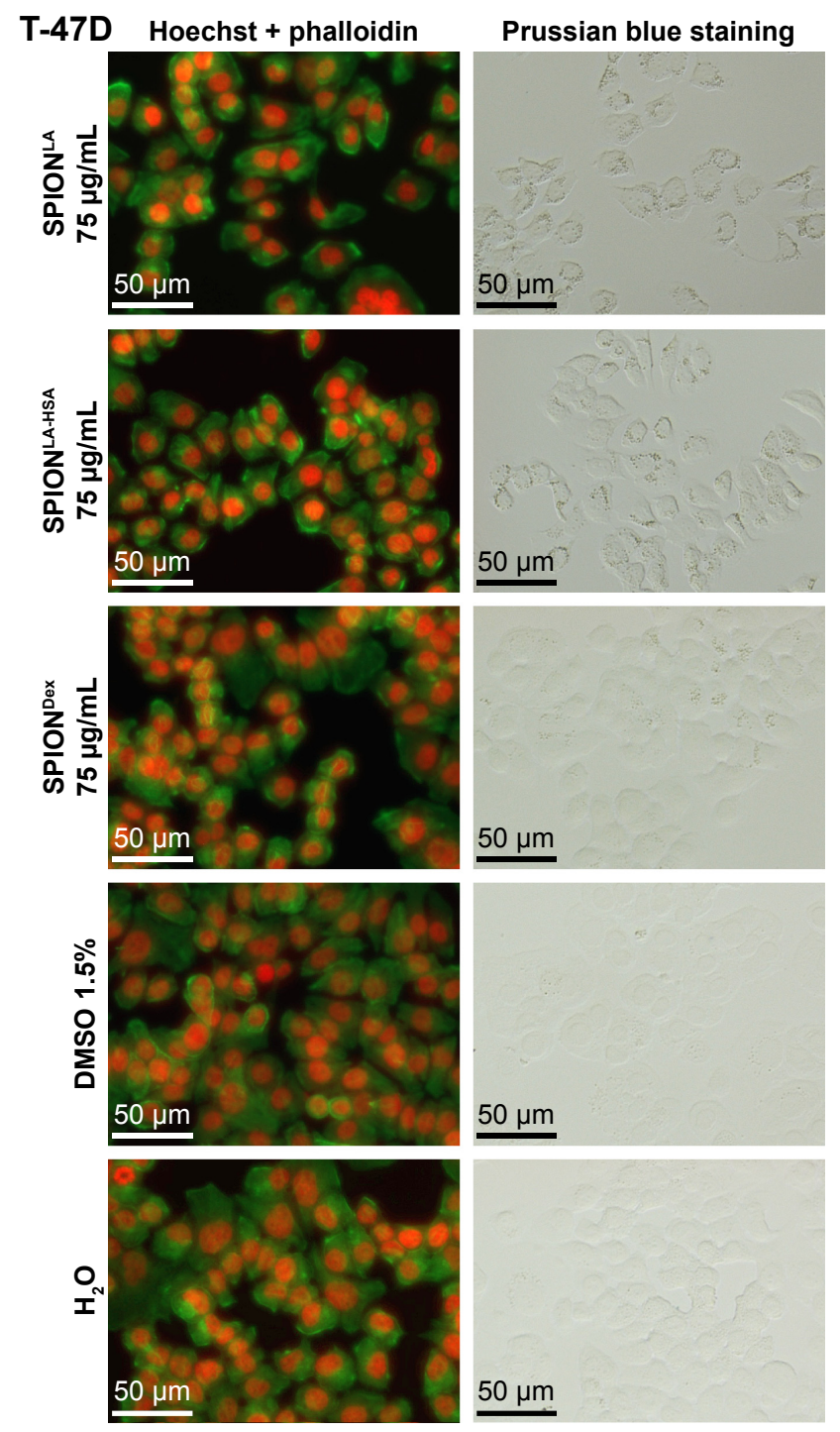

Figure 3 Images of the cellular particle load and cell morphology after SPION treatment.

Notes: T-47D cells were incubated for $48 \mathrm{~h}$ with $75 \mu \mathrm{g} / \mathrm{mL}$ SPION ${ }^{L A}$, SPION ${ }^{\text {LA-HSA }}$ and SPIONDex. Cells were imaged with a fluorescence microscope. Cells stained with Alexa Fluor 488 Phalloidin (green) and Hoechst 33342 (red) images are shown in the left column, Prussian blue stainings are shown in the right column.

Abbreviations: SPION, superparamagnetic iron oxide nanoparticles; SPION ${ }^{L A}$, lauric acid-coated SPIONs; SPION ${ }^{\text {LA-HSA }}$, lauric acid- and human serum albumin-coated SPIONs; SPION ${ }^{\text {ex }}$, dextran-coated SPIONs.

independent of cancer cell type and resulted in cellular iron amounts of 1.4 to $1.6 \mathrm{pg}_{\mathrm{Fe}}$ /cell after $48 \mathrm{~h}$ incubation, whereas the amounts of cell-associated SPION ${ }^{\mathrm{LA}-\mathrm{HSA}}$ and SPION ${ }^{\mathrm{Dex}}$ at the highest concentration and after $48 \mathrm{~h}$ incubation were relatively low, ranging from 0.6 to $0.9 \mathrm{pg}_{\mathrm{Fe}} /$ cell and 0.2 to $0.5 \mathrm{pg}_{\mathrm{Fe}} /$ cell, respectively. Interestingly, we found a clear and significant dose-dependent uptake of all SPIONs in all cell types. Moreover, the uptake of SPION ${ }^{\mathrm{LA}}$ was always the highest, followed by SPION ${ }^{\mathrm{LA}-\mathrm{HSA}}$ and SPION ${ }^{\text {Dex }}$.

Interestingly, although the ability of HUVECs to incorporate SPION ${ }^{\mathrm{LA}-\mathrm{HSA}}$ and SPION ${ }^{\mathrm{Dex}}$ was similarly low as in cancer cells, the uptake of SPION ${ }^{\mathrm{LA}}\left(5.9 \mathrm{pg}_{\mathrm{Fe}} /\right.$ cell) by HUVECs was 3.7 times stronger than that observed in breast cancer cells. This indicates potentially severe cell typespecific effects of nanoparticles, which need to be considered during particle development and in vitro evaluation.

Recently, we showed that the cellular SPION load in HUVECs correlates with the SPION concentration within the cell culture medium. ${ }^{26}$ We now evaluated whether this is a general mechanism during cell culture experiments (Figure S1). Within the applied concentration range and after $48 \mathrm{~h}$ incubation, the cellular uptake of SPION ${ }^{\mathrm{LA}}$ highly correlated with the particle concentration in the cell culture medium $\left(R^{2}>0.94\right)$. Due to very low cellular iron amounts, the correlation between cellular SPION ${ }^{\mathrm{LA}-\mathrm{HSA}}$ or SPION ${ }^{\text {Dex }}$ and the media concentration of SPIONs was weaker $\left(R^{2}>0.83\right.$ and $R^{2}>0.74$, respectively), but still detectable.

To visualize the cellular SPION uptake, we incubated the cells for $48 \mathrm{~h}$ with $75 \mu \mathrm{g}_{\mathrm{Fe}} / \mathrm{mL}$ SPIONs in $24-$ well plates. The concentration, with reference to the cell plate area, was kept equal to the previous experiments performed in 6-well plates at $21.0 \mu \mathrm{g}_{\mathrm{Fe}} / \mathrm{cm}^{2}$ (Figures 3 and $\underline{\mathrm{S} 2}-\underline{\mathrm{S} 5}$ ). After incubation, samples were stained with Alexa Fluor 488 Phalloidin (green) and Hoechst 33342 (red) for fluorescent evaluation of cytoskeletal changes and cell numbers. In parallel, samples were stained with Prussian blue to ascertain the cellular presence and deposition of iron. In the exemplary panel presenting T-47D cells, Prussian blue staining showed a distinct, cell-associated signal after SPION ${ }^{\mathrm{LA}}$ treatment (Figure 3). This signal was still detectable after incubation of T-47D with SPION ${ }^{\mathrm{LA}-\mathrm{HSA}}$. In contrast, cells treated with SPION ${ }^{\text {Dex }}$ did not differ significantly from untreated samples. Similar results were found when analyzing the BT-474, MCF7 and MDA-MB-231 samples (Figures S2-S4). Notably, the comparison of Prussian blue staining results between different breast cancer cell lines reflected the cell dependency of iron content measured by MP-AES quantification. In contrast to the results obtained in the breast cancer cells, the HUVEC images revealed strongly reduced cell numbers after SPION ${ }^{\mathrm{LA}}$ incubation, indicating a SPION type-dependent and celldependent toxicity of nanoparticles (Figure S5).

We additionally analyzed the flow cytometry SSc data after gating on phenotypically healthy cells, characterized by $\mathrm{AxV}$ and PI double negative staining. This method was considered to correlate with cellular SPION content by measuring the cellular granularity. ${ }^{26}$ To confirm that this common principle is also valid for breast cancer cells and the SPION types used in this study, we plotted the SSc data against the results of the MP-AES measurements (Figure S6). 
The very low SPION ${ }^{\mathrm{LA}}$ and SPION ${ }^{\mathrm{LA}-\mathrm{HSA}}$ amounts in MCF7 cells, in combination with slightly increased SSc of control samples and the almost undetectable concentration of cellular SPION ${ }^{\text {Dex }}$, prevented reaching a significant correlation between SSc and SPION load. However, we found a high dependence between SSc and cellular SPION load after incubation with SPION ${ }^{\mathrm{LA}}$ particles in other cells $\left(R^{2}>0.99\right.$ in BT-474; $R^{2}>0.96$ in T-47D; $R^{2}>0.84$ in MDA-MB-231; $R^{2}>0.93$ in HUVECs). Also in SPION ${ }^{\mathrm{LA}-\mathrm{HSA}}$ samples, despite relatively low amounts of cellular SPIONs, a clear correlation between iron load and SSc was observed $\left(R^{2}>0.88\right.$ in BT-474; $R^{2}>0.97$ in T-47D; $R^{2}>0.92$ in MDA-MB-231; $R^{2}>0.97$ in HUVECs). This confirmed the utility of flow cytometry SSc measurements for cellular SPION estimation after appropriate calibration of the system.

Thus, considering the cell-dependent differences in the SSc baseline, the measured SSc increase in cells incubated with SPIONs for 24 and $48 \mathrm{~h}$ reflects the accumulation of cellular particles, comparable to the results found by the MP-AES measurements (Figure S7). SPION ${ }^{\mathrm{LA}}$ induced a significantly strong dose-dependent SSc increase in all investigated cells, whereas the SSc increase after SPION ${ }^{\text {LA-HSA }}$ and particularly SPION $^{\text {Dex }}$ incubation were less pronounced, reflecting the MP-AES measurements. The highest relative SSc increase after SPION ${ }^{\mathrm{LA}}$ treatment was found with HUVECs followed by MDA-MB-231, T-47D, BT-474 and MCF7, indicating a very cell-specific differential SPION uptake, which most likely results in strong differences in nanoparticle toxicity.

\section{Cellular SPION toxicity}

A detailed and reliable determination of nanoparticle toxicity is a crucial step during particle development and is essential to predict the possible in vivo effects. Although standard assays based on spectroscopic methods ${ }^{39,40}$ are strongly influenced by the interference of nanoparticles caused by their inherent light absorption, flow cytometry ${ }^{27,41}$ is considered a very reproducible method to study the toxicity of nanoparticles, as it enables the analysis of thousands of individual cells without interference of nanoparticles. We, therefore, used the multiparameter flow cytometry to determine the impact of 24 and $48 \mathrm{~h}$ exposure to SPIONs on apoptosis, necrosis, mitochondrial membrane integrity, cell cycle and DNA fragmentation (Figures 4, 5 and $\underline{\mathrm{S} 8}-\underline{\mathrm{S} 10}$ ). In the consequence of a large amount of generated data, only the $48 \mathrm{~h}$ results are shown in the main manuscript. AxV and PI staining, which allows differentiation between viable, apoptotic and necrotic cells, revealed a very low tendency of SPIONs to induce cell death in BT-474, T-47D and
MCF7 breast cancer cells even at the highest tested dose (Figure 4A-C). In all these samples, the amount of viable cells remained $>83 \%$, with only slight dose-dependent and cell-type-specific differences. In contrast, the relatively sensitive MDA-MB-231 cells were more susceptible to SPION treatment (Figure 4D). Particularly after SPION ${ }^{\mathrm{LA}}$ and SPION ${ }^{\mathrm{LA}-\mathrm{HSA}}$ treatment, the amount of viable cells in MDA-MB-231 population decreased in a dose-dependent manner to $63 \%$ and $66 \%$, respectively. Consistent with an almost complete inability of SPION ${ }^{\text {Dex }}$ to be incorporated into cells, those particles had only a slight effect on MDA-MB231 viability. The effects on HUVECs were strongly SPION type-dependent (Figure 4E). Although SPION ${ }^{\mathrm{LA}}$ induced a dose-dependent toxicity, with HUVEC viability reduced to $85 \%$ at the highest tested dose, SPION ${ }^{\text {LA-HSA }}$ and SPION ${ }^{\text {Dex }} \mathrm{did}$ not influence the numbers of apoptotic or necrotic cells.

Comparable results were obtained by DiIC1(5) staining using flow cytometry (Figure S10). A decrease in DilC1(5) fluorescence, which correlates with a disruption of the mitochondrial membrane potential, ${ }^{27}$ allows the detection of early events during apoptosis. In BT-474, MCF7 and T-47D cells, either none or an extremely low dose-dependent change in the mitochondrial membrane potential was detectable after for $48 \mathrm{~h}$, whereas MDA-MB-231 cells revealed a decreased, dose-dependent tolerance toward SPION ${ }^{\mathrm{LA}}$ and SPION ${ }^{\mathrm{LA}}$ HSA particles. In contrast to breast cancer cells, incubation of SPION ${ }^{\mathrm{LA}}$ with HUVECs had more severe consequences for cell viability by inducing a concentration-dependent collapse of the mitochondrial membrane potential and finally cell death.

Finally, PI/Triton X-100 (PIT) staining in cells incubated for $48 \mathrm{~h}$ with SPIONs was performed to investigate cell cycle stage, proliferation status and DNA degradation during apoptosis (Figure 5). ${ }^{28}$ Notably, the proliferation rate, indicated by the portion of cells with double diploid DNA, differs between the cell types (BT-474, 47\%; MCF7, 46\%; MDA-MB-231, $34 \%$; T-47D, 30\%; HUVECs 27\%) and reflects the growth speed of the cells. SPION treatment of breast cancer cells did not significantly influence cell cycle and DNA degradation. In contrast, the amount of damaged DNA increased dose-dependently from $8 \%$ to $64 \%$ in HUVECs treated with SPION $^{\mathrm{LA}}$, while diploid DNA decreased from $65 \%$ to $29 \%$ and double diploid DNA decreased from $27 \%$ to $7 \%$, indicating a severe dose-dependent toxicity of SPION ${ }^{\mathrm{LA}}$ in HUVECs.

\section{Discussion}

Our investigations, addressing different types of SPIONs and their effects on distinct cell types, revealed several 


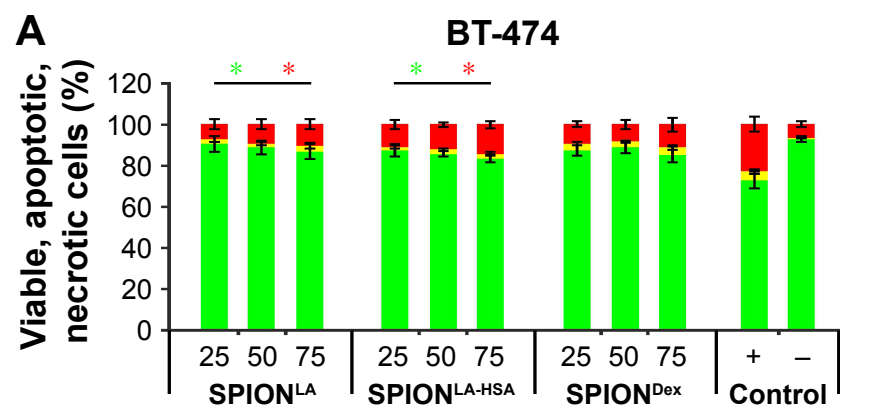

SPION concentration ( $\mu \mathrm{g} / \mathrm{mL}$ cell medium)

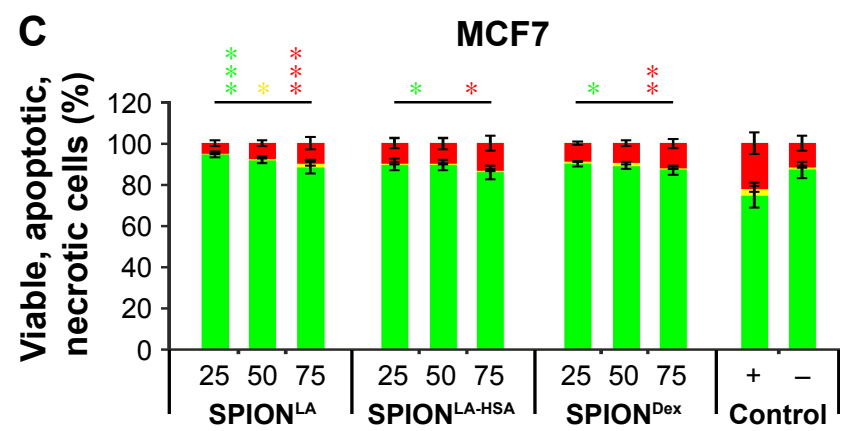

SPION concentration ( $\mu \mathrm{g} / \mathrm{mL}$ cell medium)

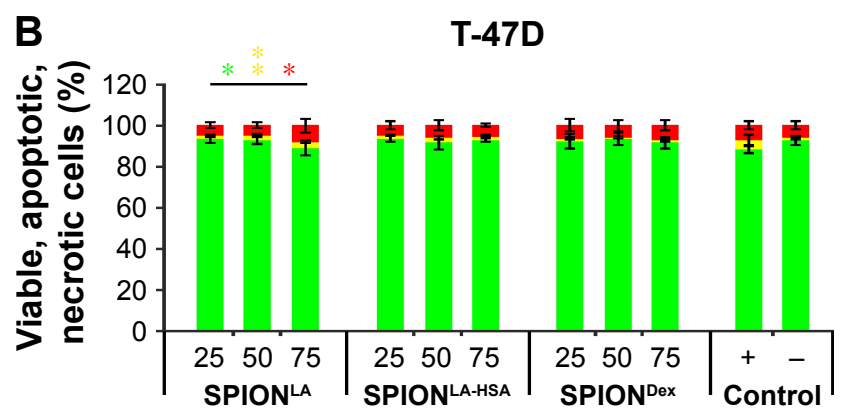

SPION concentration ( $\mu \mathrm{g} / \mathrm{mL}$ cell medium)

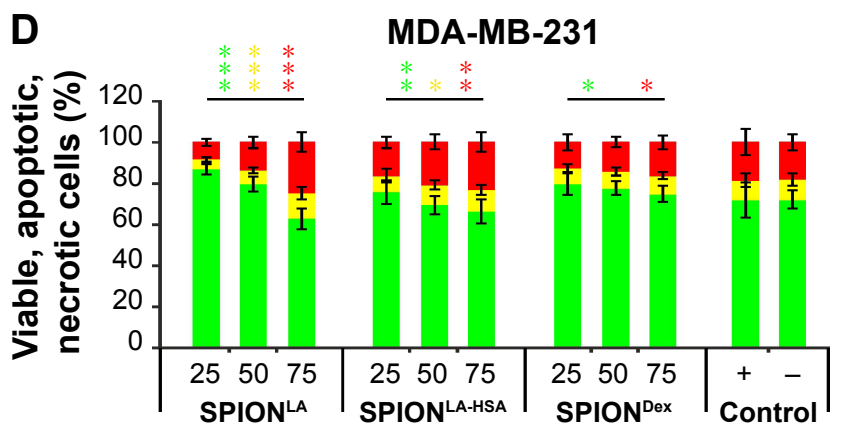

SPION concentration ( $\mu \mathrm{g} / \mathrm{mL}$ cell medium)

E

HUVECs

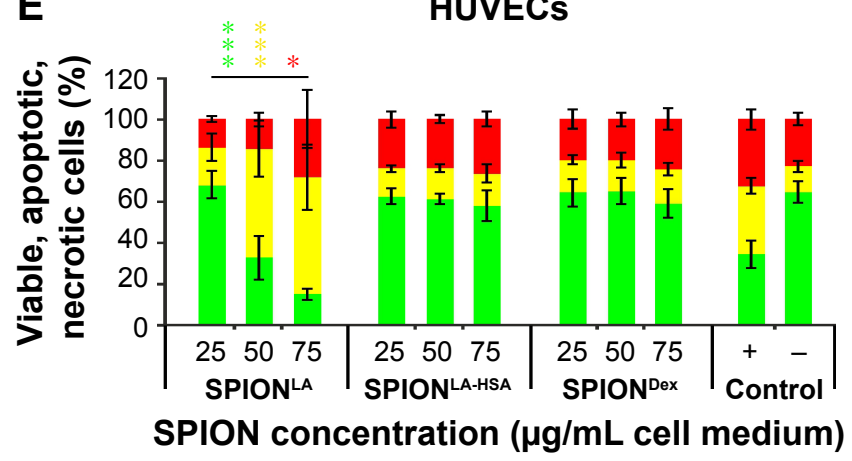

Necrosis Apoptosis Viable cells

Figure 4 Viability of different cells after SPION treatment.

Notes: Cells were incubated for $48 \mathrm{~h}$ with increasing amounts of SPION ${ }^{L A}$, SPION ${ }^{\text {LA-HSA }}$ and SPIONDex. Cell viability was determined by annexin A5-FITC/PI staining and analyzed by flow cytometry. The amount of viable (Ax-PI-), apoptotic (Ax+PI-) and necrotic (PI+) cells are shown for (A) BT-474, (B) T-47D, (C) MCF7, (D) MDA-MB-23 I and (E) HUVEC cells. Positive controls contain $2 \%$ DMSO, and negative controls represent the corresponding amount of $\mathrm{H}_{2} \mathrm{O}$ instead of water-based ferrofluid. Data are expressed as the mean \pm standard deviation ( $n=4$ with technical triplicates). Statistical significance of $48 \mathrm{~h}$ data sets are indicated with $* P<0.05$, $* * P<0.00 \mathrm{I}$ and $* * * P<0.000 \mathrm{I}$ and were calculated via Student's t-test analysis. Colored asterisks indicate dose-dependent significance between lowest and highest SPION concentrations on necrosis (red asterisks), apoptosis (yellow asterisks) and viability (green asterisks).

Abbreviations: SPION, superparamagnetic iron oxide nanoparticles; SPION ${ }^{L A}$, lauric acid-coated SPIONs; SPION ${ }^{L A-H S A}$, lauric acid- and human serum albumin-coated SPIONs; SPION ${ }^{\text {ex }}$, dextran-coated SPIONs; PI, propidium iodide; HUVECs, human umbilical vein endothelial cells; Ax-PI-, annexin V-FITC negative and Propidium iodide negative; $\mathrm{Ax}+\mathrm{PI}-$, annexin $\mathrm{V}$-FITC positive and propidium iodide negative; $\mathrm{PI}+$, propidium iodide positive.

particle- and cell type- as well as concentration- and time-dependent effects on particle uptake and toxicity. Despite their very similar nature, SPION ${ }^{\mathrm{LA}}$ and SPION ${ }^{\mathrm{LA}-\mathrm{HSA}}$ behaved entirely different, both concerning the cellular uptake and toxicity. For SPION ${ }^{\mathrm{LA}}$, the cellular iron load was $\sim 2$ times higher than for SPION ${ }^{\mathrm{LA}-\mathrm{HSA}}$ in breast cancer cells and up to 6 times higher in HUVECs. This is an interesting observation, as it clearly illustrates how far the properties of SPIONs can be altered by modifications in particle synthesis and functionalization. SPION ${ }^{\mathrm{LA}-\mathrm{HSA}}$ are produced by coating SPION ${ }^{\mathrm{LA}}$ with human serum albumin. ${ }^{36}$ Consequently, the presence of a strong stabilizing protein corona is the only difference between these particles. This difference dictates the properties and strongly influences the toxicity of the particles, at least until they come in contact with FCS-containing media, when SPION ${ }^{\mathrm{LA}}$ particles are immediately surrounded by FCS proteins, mainly albumins. ${ }^{42}$ By contact with protein-containing media, the differences 


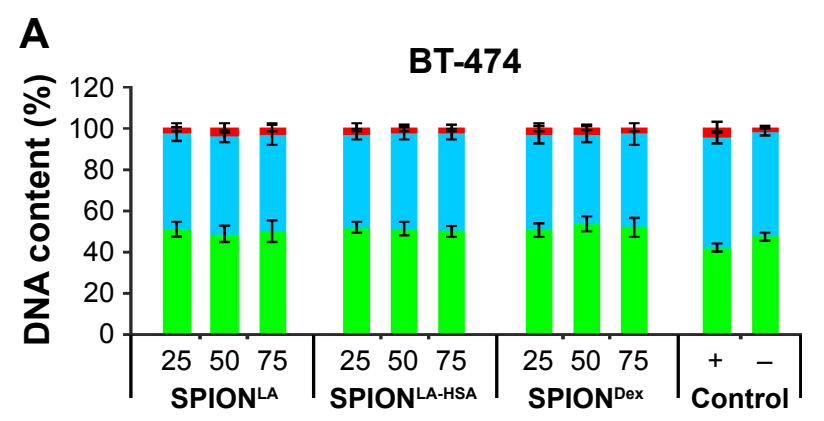

SPION concentration $(\mu \mathrm{g} / \mathrm{mL}$ cell medium)

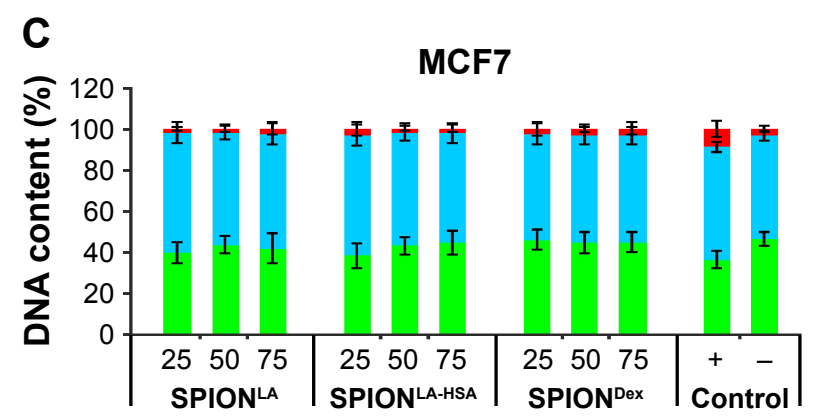

SPION concentration $(\mu \mathrm{g} / \mathrm{mL}$ cell medium)

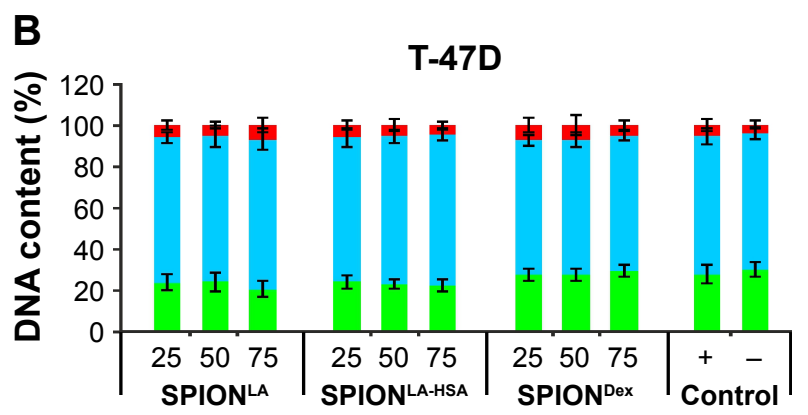

SPION concentration ( $\mu \mathrm{g} / \mathrm{mL}$ cell medium)

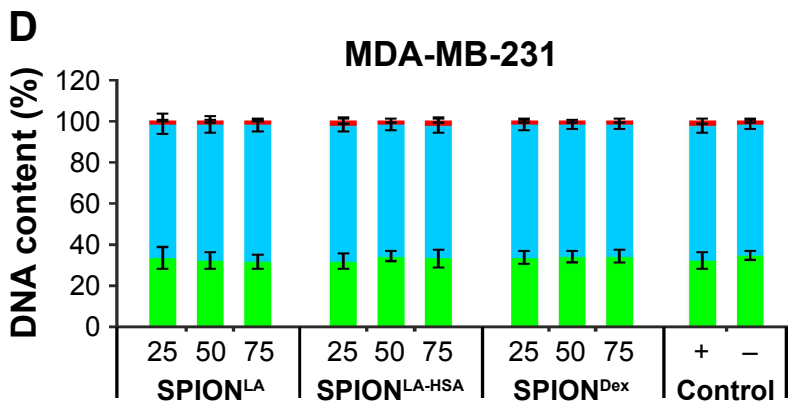

SPION concentration ( $\mu \mathrm{g} / \mathrm{mL}$ cell medium)

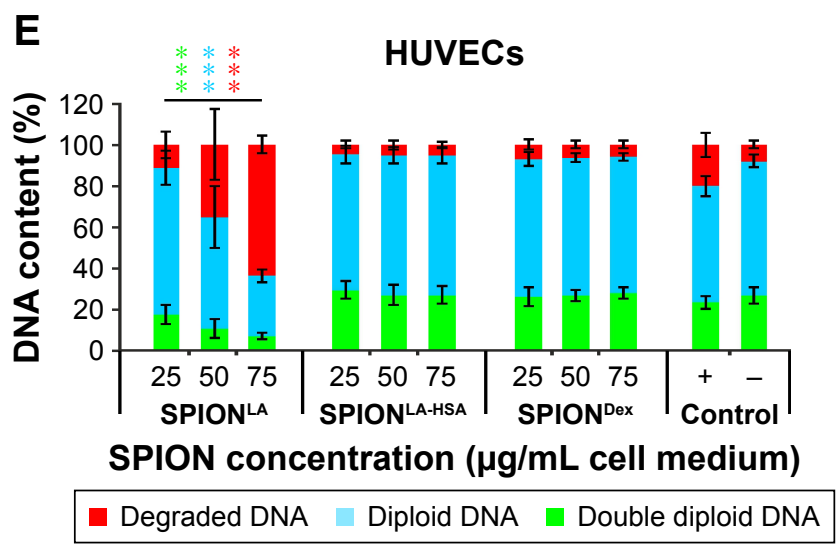

Figure 5 DNA degradation and cell cycle analysis by propidium iodide-triton $X$ (PIT) staining.

Notes: Cells were incubated for $48 \mathrm{~h}$ with increasing amounts of SPION ${ }^{L A}$, SPION ${ }^{\text {LA-HSA }}$ and SPIONDex and analyzed by flow cytometry. The DNA conditions are shown for (A) BT-474, (B) T-47D, (C) MCF7, (D) MDA-MB-23I and (E) HUVEC cells as the amount of degraded DNA, diploid DNA (GI-phase) and double diploid DNA (synthesis/ G2-phase). Positive controls contain $2 \%$ DMSO, negative controls represent the corresponding amount of $\mathrm{H}_{2} \mathrm{O}$ instead of water-based ferrofluid. Data are expressed as the mean \pm standard deviation ( $\mathrm{n}=4$ with technical triplicates). Statistical significance of $48 \mathrm{~h}$ data sets are indicated with $* * * P<0.000 \mathrm{I}$ and were calculated via Student's $t$-test analysis. Colored asterisks indicate dose-dependent significance between lowest and highest SPION concentrations on degraded DNA (red asterisks), diploid DNA (blue asterisks) and double diploid DNA (green asterisks).

Abbreviations: SPION, superparamagnetic iron oxide nanoparticles; SPION ${ }^{L A}$, lauric acid-coated SPIONs; SPION ${ }^{\text {LA-HSA }}$, lauric acid- and human serum albumin-coated SPIONs; SPION ${ }^{\text {ex }}$, dextran-coated SPIONs; HUVECs, human umbilical vein endothelial cells.

between SPION ${ }^{\mathrm{LA}}$ and SPION ${ }^{\mathrm{LA}-\mathrm{HSA}}$ are diminished, although SPION ${ }^{\mathrm{LA}-\mathrm{HSA}}$ remains the most stable lauric acid-containing SPION particle system.

The stability of particles is a commonly underestimated factor influencing particle uptake and toxicity. Even though the investigated particles were not susceptible to agglomeration in biological fluids (Figure 1D), they may have a particleinherent tendency to sediment over time. ${ }^{43,44}$ Centrifugation experiments of particles suspended in media containing $2 \%$
FCS revealed a relatively high sedimentation tendency of SPION ${ }^{L A}$, compared to $10 \%$ FCS. This is in accordance with the previous report, which showed that an increased concentration of proteins in the cell culture media can have positive effects on agglomeration and sedimentation propensity of nanoparticles. ${ }^{45}$ Thus, enhanced sedimentation is probably the main reason of the increased cellular uptake of SPION ${ }^{\mathrm{LA}}$ and their subsequent toxicity in HUVECs, which are cultivated in medium supplemented with $2 \% \mathrm{FCS}$, compared to the breast 
cancer cells, which are grown in media with $8 \%-10 \%$ FCS. In contrast, SPION ${ }^{\mathrm{LA}-\mathrm{HSA}}$ and notably SPION ${ }^{\text {Dex }}$ had a very low sedimentation rate, independent of the FCS concentration (Figure 1C). Unlike soluble chemicals, sedimentation of nanoparticles can significantly affect the cellular dosage by increasing the effective concentrations in static conditions and thus cell-particle interactions. ${ }^{46}$ In our in vitro experiments, the probability of a partial sedimentation during cell culture experiments is higher with SPION ${ }^{\mathrm{LA}}$ followed by SPION $^{\text {LA-HSA }}$ and SPION ${ }^{\text {Dex }}$, which possibly results in higher SPION ${ }^{L A}$ uptake and toxicity. To what extent sedimentation of these SPIONs influences dose-response curves ${ }^{47}$ and how the uptake and toxicity can affect the in vivo administration are difficult to foresee. Models and methodologies for particle dosimetry that enables the determination of the dosage delivered to cells have already been presented, and it has been shown that usage of the cellular dose rather than administered dose improves the correlation between dose and response to particles in vitro and in vivo. ${ }^{48-51}$

In addition to the impact of SPION-intrinsic properties, we found some strongly pronounced cell type-dependent differences affecting cellular SPION uptake. In our studies, we used 4 different breast cancer cell lines that strongly differ from each other concerning the expression of estrogen receptor (ER), progesterone receptor $(\mathrm{PR})$, human epidermal growth factor receptor 2 (Her2/ERBB2) and a cellular proliferation marker Ki-67. Hence, these cells can be categorized into different breast cancer subtypes: MDA-MB-231 is a basal-like subtype and triple negative to ER, PR and HER2; BT-474 belongs to the luminal B subtype and triple positive to ER, PR and HER2; MCF7 and T-47D are both positive to ER and PR and negative to HER2. Both are mostly categorized into the luminal A subtype, but the $\mathrm{Ki}-67$ expression in MCF7 is high, whereas Ki-67 expression in T-47D is low. ${ }^{22,23}$ This difference in the proliferation rate between MCF7 and T-47D was verified in our cell cycle and DNA degradation analysis (Figure 5). Furthermore, HUVECs were included in our studies, as a tumor-unrelated control. We have found that breast cancer cells incorporate between 1.4 and $1.7 \mathrm{pg}$ SPION ${ }^{\mathrm{LA}}$ (medium concentration: $75 \mu \mathrm{g}_{\mathrm{Fe}} / \mathrm{mL}$ ) after $48 \mathrm{~h}$ of incubation, whereas HUVECs contained 5.9 pg SPION ${ }^{\text {LA }}$ (Figures 2 and $\underline{\mathrm{S} 1}$ ). This clearly demonstrates a strong influence of the cell type on particle uptake, suggesting differences in the cell-specific activity of the 2 main endocytic pathways, phagocytosis and pinocytosis, as well as exocytosis. ${ }^{52}$

Apart from the highly accurate MP-AES method for cellular iron quantification, we evaluated the possibility of using flow cytometric SSc data to estimate the cellular
SPION load in human breast cancer cells (iures S6 and $\underline{\text { S7 }}$ ). We have previously demonstrated the applicability of this method to determine the absolute cellular amount of different SPIONs in HUVECs. ${ }^{26}$ We now tested whether this method is feasible also for other cells, which would be of great value for flow cytometry experiments by providing an additional important parameter. All cells incubated with SPION $^{\mathrm{LA}}$ and SPION ${ }^{\mathrm{LA}-H S A}$ except for MCF7 demonstrated a high cell-dependent correlation between iron load and SSc. Due to the very low SPION uptake, MCF7 cells and cells incubated with SPIONDex did not display a significant SSc increase and consequently no reliable correlation. Hence, SSc data can be used to estimate the cellular SPION amount, assuming that the SPION load exceeds $1.5 \mathrm{pg}_{\mathrm{Fe}} /$ cell, and the system is calibrated properly.

We finally performed a detailed analysis of the toxic effects of SPIONs by flow cytometry (Figures 4, 5 and $\underline{\text { S8}}-\underline{\text { S10)}}$. Remarkably, we did not find a direct correlation between SPION load and toxicity in general. In spite of the increased SPION ${ }^{\mathrm{LA}}$ content in BT-474, T47D and MCF7 cells, the numbers of apoptotic or necrotic cells were only marginally altered. Similar results were found when analyzing the changes in the mitochondrial membrane potential, DNA degradation and cell cycle. In contrast, MDA-MB-231 cells, containing similar amounts of SPION ${ }^{\mathrm{LA}} /$ cell, showed much higher sensitivity reflected by a clear, dose-dependent increase in apoptosis and necrosis, as well as decreased mitochondrial membrane potential. Interestingly, the cell cycle was not influenced in those cells, indicating a differential cellular response to SPIONs. Compared to breast cancer cells, the exposure of HUVECs to SPIONLA resulted in dramatically reduced cell viability, whereas SPION ${ }^{\text {LA-HSA }}$ and SPION ${ }^{\text {Dex }}$ had only a minor effect on HUVECs at the highest tested concentration. Thus, the flow cytometry analysis showed very low cytotoxic effects of SPION ${ }^{\text {LA-HSA }}$ and SPIONDex in all cell types even at very high concentrations. In contrast, SPION ${ }^{\mathrm{LA}}$ had a very heterogeneous impact on different cell types, ranging from highly toxic effect in HUVECs to principally nontoxic effect on BT-474, MCF7 and T-47D cells.

\section{Conclusion}

We found that the particle internalization by cells is strongly related to the SPION-surface coating. Moreover, our studies demonstrated a highly cell type-dependent SPION uptake and toxicity that determine the possible areas of application. SPION ${ }^{\mathrm{LA}}$ are relatively nontoxic to breast cancer cells and could easily be functionalized to target these cells, but 
they are harmful to HUVECs and possibly also to other healthy cells. Due to this fact, there is a risk of enhanced toxicity if these particles escape the tumor targeting, which excludes their clinical use. SPION ${ }^{\text {Dex }}$, showing a high stability, extremely low toxicity and barely detectable cell uptake, can be considered a suitable candidate for MRI. Compared with SPION ${ }^{\text {Dex }}$, SPION ${ }^{\mathrm{LA}-\mathrm{HSA}}$ are more suitable for hyperthermia and, upon drug loading, for MDT, based on their good magnetic properties, adequate stability and low toxicity. Additionally, SPION ${ }^{\mathrm{LA}-\mathrm{HSA}}$ could easily be utilized for MRI, thus enabling theranostic applications. Future in vivo experiments are necessary to determine the theranostic capabilities of SPION ${ }^{\text {LA-HSA }}$.

\section{Acknowledgments}

The present work was performed in fulfillment of the requirements for obtaining the degree "Dr. med.". This study was supported by the Deutsche Forschungsgemeinschaft (SPP1681: grant numbers AL 552/5-2, TR408/8 and WI4230/1); Manfred-Roth-Stiftung, Fürth; Verein zur Förderung des Tumorzentrums der Universität ErlangenNürnberg e.V.; and Engineering of Advanced Materials (EAM). We acknowledge the support by Deutsche Forschungsgemeinschaft and Friedrich-AlexanderUniversität Erlangen-Nürnberg (FAU) within the funding program Open Access Publishing. The authors thank Dr Iwona Cicha for English language editing. Bianca Weigel and Julia Band are gratefully acknowledged for their expert technical help with the cell culture.

\section{Disclosure}

The authors report no conflicts of interest in this work.

\section{References}

1. World Health Organization, Switzerland. Global Health Estimates 2015, Summary Tables: Global summary estimates, Estimated deaths by cause 2015. Available from: http://www.who.int/entity/healthinfo/ global_burden_disease/GHE2015_Deaths_Global_2000_2015.xls?ua=1. Accessed March 17, 2017.

2. Youlden DR, Cramb SM, Dunn NA, Muller JM, Pyke CM, Baade PD. The descriptive epidemiology of female breast cancer: an international comparison of screening, incidence, survival and mortality. Cancer Epidemiol. 2012;36(3):237-248.

3. PDQ Adult Treatment Editorial Board. Breast cancer treatment (PDQ $\left.{ }^{\circledR}\right)$ : health professional version. $P D Q$ Cancer Information Summaries. Bethesda, MD: National Cancer Institute (US); 2002.

4. Chen L, Linden HM, Anderson BO, Li CI. Trends in 5-year survival rates among breast cancer patients by hormone receptor status and stage. Breast Cancer Res Treat. 2014;147(3):609-616.

5. Shapiro CL, Recht A. Side effects of adjuvant treatment of breast cancer. N Engl J Med. 2001;344(26):1997-2008.

6. Long NV, Yang Y, Teranishi T, Thi CM, Cao Y, Nogami M. Biomedical applications of advanced multifunctional magnetic nanoparticles. J Nanosci Nanotechnol. 2015;15(12):10091-10107.
7. Lyer S, Tietze R, Jurgons R, et al. Visualisation of tumour regression after local chemotherapy with magnetic nanoparticles - a pilot study. Anticancer Res. 2010;30(5):1553-1557.

8. Laurent S, Dutz S, Hafeli UO, Mahmoudi M. Magnetic fluid hyperthermia: focus on superparamagnetic iron oxide nanoparticles. $A d v$ Colloid Interface Sci. 2011;166(1-2):8-23.

9. Liu F, Laurent S, Fattahi H, Vander Elst L, Muller RN. Superparamagnetic nanosystems based on iron oxide nanoparticles for biomedical imaging. Nanomedicine (Lond). 2011;6(3):519-528.

10. Durr S, Schmidt W, Janko C, et al. A novel magnetic field device for inducing hyperthermia using magnetic nanoparticles. Biomed Tech (Berl). Epub 2013 Sep 7.

11. Lee IJ, Ahn CH, Cha EJ, Chung IJ, Chung JW, Kim YI. Improved drug targeting to liver tumors after intra-arterial delivery using superparamagnetic iron oxide and iodized oil: preclinical study in a rabbit model. Invest Radiol. 2013;48(12):826-833.

12. Tietze R, Zaloga J, Unterweger H, et al. Magnetic nanoparticle-based drug delivery for cancer therapy. Biochem Biophys Res Commun. 2015; 468(3):463-470.

13. Janko C, Durr S, Munoz LE, et al. Magnetic drug targeting reduces the chemotherapeutic burden on circulating leukocytes. Int J Mol Sci. 2013;14(4):7341-7355.

14. Kobayashi T. Cancer hyperthermia using magnetic nanoparticles. Biotechnol J. 2011;6(11):1342-1347.

15. Jin R, Lin B, Li D, Ai H. Superparamagnetic iron oxide nanoparticles for MR imaging and therapy: design considerations and clinical applications. Curr Opin Pharmacol. 2014;18:18-27.

16. Wahajuddin, Arora S. Superparamagnetic iron oxide nanoparticles: magnetic nanoplatforms as drug carriers. Int J Nanomedicine. 2012;7:3445-3471.

17. Mahmoudi M, Sant S, Wang B, Laurent S, Sen T. Superparamagnetic iron oxide nanoparticles (SPIONs): development, surface modification and applications in chemotherapy. Adv Drug Deliv Rev. 2011;63(1-2): 24-46.

18. Gobbo OL, Sjaastad K, Radomski MW, Volkov Y, Prina-Mello A. Magnetic nanoparticles in cancer theranostics. Theranostics. 2015; 5(11):1249-1263.

19. Stirland DL, Nichols JW, Miura S, Bae YH. Mind the gap: a survey of how cancer drug carriers are susceptible to the gap between research and practice. J Control Release. 2013;172(3):1045-1064.

20. Zaloga J, Pottler M, Leitinger G, et al. Pharmaceutical formulation of HSA hybrid coated iron oxide nanoparticles for magnetic drug targeting. Eur J Pharm Biopharm. 2016;101:152-162.

21. Pottler M, Staicu A, Zaloga J, et al. Genotoxicity of superparamagnetic iron oxide nanoparticles in granulosa cells. Int J Mol Sci. 2015; 16(11):26280-26290.

22. Jiang G, Zhang S, Yazdanparast A, et al. Comprehensive comparison of molecular portraits between cell lines and tumors in breast cancer. BMC Genomics. 2016;17(suppl 7):525.

23. Chekhun S, Bezdenezhnykh N, Shvets J, Lukianova N. Expression of biomarkers related to cell adhesion, metastasis and invasion of breast cancer cell lines of different molecular subtype. Exp Oncol. 2013; 35(3):174-179.

24. Zaloga J, Stapf M, Nowak J, et al. Tangential flow ultrafiltration allows purification and concentration of lauric acid-/albumin-coated particles for improved magnetic treatment. Int J Mol Sci. 2015;16(8): 19291-19307.

25. Unterweger H, Subatzus D, Tietze R, et al. Hypericin-bearing magnetic iron oxide nanoparticles for selective drug delivery in photodynamic therapy. Int J Nanomedicine. 2015;10:6985-6996.

26. Friedrich RP, Janko C, Poettler M, et al. Flow cytometry for intracellular SPION quantification: specificity and sensitivity in comparison with spectroscopic methods. Int J Nanomedicine. 2015;10:4185-4201.

27. Munoz LE, Maueroder C, Chaurio R, Berens C, Herrmann M, Janko C. Colourful death: six-parameter classification of cell death by flow cytometry - dead cells tell tales. Autoimmunity. 2013;46(5): $336-341$. 
28. Riccardi C, Nicoletti I. Analysis of apoptosis by propidium iodide staining and flow cytometry. Nat Protoc. 2006;1(3):1458-1461.

29. Hunt CP, Moskowitz BM, Banerjee SK. Magnetic properties of rocks and minerals. In: Ahrens TJ, editor. Rock Physics and Phase Relations: A Handbook of Physical Constants. Washington, DC: American Geophysical Union; 1995:189.

30. Unterweger H, Tietze R, Janko C, et al. Development and characterization of magnetic iron oxide nanoparticles with a cisplatin-bearing polymer coating for targeted drug delivery. Int J Nanomedicine. 2014;9: 3659-3676.

31. Saito S, Tsugeno M, Koto D, et al. Impact of surface coating and particle size on the uptake of small and ultrasmall superparamagnetic iron oxide nanoparticles by macrophages. Int J Nanomedicine. 2012;7: 5415-5421.

32. Calatayud MP, Sanz B, Raffa V, Riggio C, Ibarra MR, Goya GF. The effect of surface charge of functionalized Fe3O4 nanoparticles on protein adsorption and cell uptake. Biomaterials. 2014;35(24):6389-6399.

33. Tenzer S, Docter D, Kuharev J, et al. Rapid formation of plasma protein corona critically affects nanoparticle pathophysiology. Nat Nanotechnol. 2013;8(10):772-781.

34. Shen L, Laibinis PE, Hatton TA. Bilayer surfactant stabilized magnetic fluids: synthesis and interactions at interfaces. Langmuir. 1999; 15(2):447-453.

35. Gebauer JS, Malissek M, Simon S, et al. Impact of the nanoparticleprotein corona on colloidal stability and protein structure. Langmuir. 2012;28(25):9673-9679.

36. Zaloga J, Janko C, Nowak J, et al. Development of a lauric acid/albumin hybrid iron oxide nanoparticle system with improved biocompatibility. Int J Nanomedicine. 2014;9:4847-4866.

37. Tietze R, Rahn H, Lyer S, et al. Visualization of superparamagnetic nanoparticles in vascular tissue using XmuCT and histology. Histochem Cell Biol. 2011;135(2):153-158.

38. Li W, Simmons P, Shrader D, Herrman TJ, Dai SY. Microwave plasmaatomic emission spectroscopy as a tool for the determination of copper, iron, manganese and zinc in animal feed and fertilizer. Talanta. 2013;112:43-48.

39. Almutary A, Sanderson BJ. The MTT and crystal violet assays: potential confounders in nanoparticle toxicity testing. Int J Toxicol. 2016; 35(4):454-462.

40. Kumar G, Degheidy H, Casey BJ, Goering PL. Flow cytometry evaluation of in vitro cellular necrosis and apoptosis induced by silver nanoparticles. Food Chem Toxicol. 2015;85:45-51.
41. Janko C, Munoz L, Chaurio R, et al. Navigation to the graveyardinduction of various pathways of necrosis and their classification by flow cytometry. Methods Mol Biol. 2013;1004:3-15.

42. Rahman M, Laurent S, Tawil N, Yahia L, Mahmoudi M, editors. Protein-nanoparticle interactions: the bio-nano interface. In: Springer Series in Biophysics. Berlin, Heidelberg: Springer Berlin Heidelberg; 2013:15.

43. Hinderliter PM, Minard KR, Orr G, et al. ISDD: a computational model of particle sedimentation, diffusion and target cell dosimetry for in vitro toxicity studies. Part Fibre Toxicol. 2010;7(1):36.

44. Cho EC, Zhang Q, Xia Y. The effect of sedimentation and diffusion on cellular uptake of gold nanoparticles. Nat Nanotechnol. 2011;6(6): 385-391.

45. Allouni ZE, Cimpan MR, Hol PJ, Skodvin T, Gjerdet NR. Agglomeration and sedimentation of $\mathrm{TiO} 2$ nanoparticles in cell culture medium. Colloids Surf B Biointerfaces. 2009;68(1):83-87.

46. Matuszak J, Baumgartner J, Zaloga J, et al. Nanoparticles for intravascular applications: physicochemical characterization and cytotoxicity testing. Nanomedicine (Lond). 2016;11(6):597-616.

47. Matuszak J, Dorfler P, Zaloga J, et al. Shell matters: magnetic targeting of SPIONs and in vitro effects on endothelial and monocytic cell function. Clin Hemorheol Microcirc. 2015;61(2):259-277.

48. Cohen JM, Teeguarden JG, Demokritou P. An integrated approach for the in vitro dosimetry of engineered nanomaterials. Part Fibre Toxicol. 2014;11:20.

49. Mukherjee D, Leo BF, Royce SG, et al. Modeling physicochemical interactions affecting in vitro cellular dosimetry of engineered nanomaterials: application to nanosilver. J Nanopart Res. 2014;16(10):2616.

50. Teeguarden JG, Hinderliter PM, Orr G, Thrall BD, Pounds JG. Particokinetics in vitro: dosimetry considerations for in vitro nanoparticle toxicity assessments. Toxicol Sci. 2007;95(2):300-312.

51. Teeguarden JG, Mikheev VB, Minard KR, et al. Comparative iron oxide nanoparticle cellular dosimetry and response in mice by the inhalation and liquid cell culture exposure routes. Part Fibre Toxicol. 2014; 11:46.

52. Yameen B, Choi WI, Vilos C, Swami A, Shi J, Farokhzad OC. Insight into nanoparticle cellular uptake and intracellular targeting. J Control Release. 2014;190:485-499.
International Journal of Nanomedicine

\section{Publish your work in this journal}

The International Journal of Nanomedicine is an international, peerreviewed journal focusing on the application of nanotechnology in diagnostics, therapeutics, and drug delivery systems throughout the biomedical field. This journal is indexed on PubMed Central, MedLine, CAS, SciSearch $®$, Current Contents ${ }^{\circledR} /$ Clinical Medicine,

\section{Dovepress}

Journal Citation Reports/Science Edition, EMBase, Scopus and the Elsevier Bibliographic databases. The manuscript management system is completely online and includes a very quick and fair peer-review system, which is all easy to use. Visit http://www.dovepress.com/ testimonials.php to read real quotes from published authors. 